\title{
6
}

\section{State Art, the Novel, and Architecture: Intersections}

It is important for the materialist historian, in the most rigorous way possible, to differentiate the construction of a historical state of affairs from what one customarily calls its 'reconstruction'. The 'reconstruction' in empathy is one-dimensional. 'Construction' presupposes 'destruction'.

-Benjamin (Arcades, [N7, 6], 470)

Within the system of State art, the Italian novel was expected to create and to build the moral discursive space of the regime and, therefore, to contribute to the modernization of the publishing industry, just as architecture was supposed to shape the physical and symbolic spaces constructed by the anthropological revolution ignited by the regime, which aimed to accommodate the New Man, as discussed in Chap. 4. These complementary artistic projects thus worked in tandem towards the creation of a Fascist aesthetics (arte di Stato), a New Fascist Man and a Fascist modernity, together translating into a process of modernization of the public sphere. Their shared basis was their constructive effort, to be achieved through the rationalization of forms (a 'return to the simplicity and essentiality of expressive means'), an adherence to the real, the use of anti-subjective, anti-Romantic aesthetic codes, and an attention to the 
contextual reality, all of which enabled individual subjectivity to be transformed into a collective experience. What, then, is the relationship between the foundational principles of the novel and this new architectural aesthetics? A preliminary answer would be that among the many facets of the anthropological revolution for the control of the individual made collective were the reconstruction of the novel in realist tones, so that it could reach the middle and lower-middle classes, and the promotion of a rationalized spatial dimension for the arts. This topic was often discussed in cultural and literary journals and periodicals, with some notable debates taking place on the fringes of the official landscape.

\section{Intersections}

In this chapter, our focus is on the discursive intersections between realism in prose writing and the call for the renewal of architectural forms, since both projects are part of a wider discourse on modernity as a theoretical premise and on modernization as a practical intervention in the public sphere, particularly in the first half of the 1930s (see Chap. 2). ${ }^{1}$ The key journals which engaged in a wide-ranging debate about these sets of interlocking issues are: Il Saggiatore (Rome, 1930-1933), Orpheus (Milan, 1932-1935) and Occidente (Rome, 1932-1935); unlike periodicals such as Berto Ricci's L'Universale (1931-1935), these three were not grown out of the university youth Fascist groups GUF (gruppi universitari fascisti). All three stopped their publications at the peak of the regime's popularity, and before that point they articulated an understanding of the arts from an international and interdisciplinary perspective.

However, in order to give a full picture of the wider debate on these themes, we will make references where appropriate to other journals on the cultural fringes of the avant-gardes, such as Interplanetario (1928) for the arts generally and La ruota dentata (1927) for the visual arts, and to others which promoted the mainstream cultural line at the core of the national tradition in political, cultural and literary terms, such as L'Italia letteraria (Rome, 1928-1936) or Critica fascista (Rome, 1923-1943). ${ }^{2}$ Furthermore, aside from L'Italia letteraria (and its other incarnations) 
and Critica fascista, all our journals lived short lives, from 1932, from the year of the Mostra della Rivoluzione Fascista and the celebrations for the Decennale, until 1936, with the establishment of the empire and the last public appearance of the grande dame of the arts, Margherita Sarfatti, and the regime's progressive political isolation. As a corpus, these three journals in particular recorded the steps taken during the most important period in the history of the relationships between aesthetics and politics during the Ventennio, and also followed the declining curve of rationalist architecture. We have chosen journals associated with the young intelligentsia, because of the attention they paid to the European dimension of culture, to realism, and to interdisciplinary connections across the system of the arts. It was primarily within the regime's youth culture that new spaces for intellectual and cultural dialogue could be carved out and alternative theoretical positions on the arts suggested under the regime (Sechi 1984; Ben-Ghiat 2001). Unlike the Immaginist movement and the Roman underground circles, for instance, with their surrealist, antiestablishment and hyperrealist underpinnings, the journals-produced within the groupings of the regime's youth culture-provided a platform for ideas, which looked towards the international sphere to reach beyond the limits of a statist, State patronage-based approach and encourage critical, as well as self-critical, reflection on the status quo, on the future, and on modernity itself (Carpi 1981a, 117-20).

\section{The Principles}

Between 1932 and 1936, the regime reached a peak not only in terms of consensus, but also of visibility (Corner 2012, 143-45; Colarizzi $2000,105-16)$. If in political terms the first half of the 1930s represented the regime's most successful years, in aesthetic terms it translated into a desire for the so-called return to realism, to 'structurally concluded forms', following the strong anti-bourgeois ideological stance the regime had assumed in the early days: in a nutshell, a decade later, this was a return to construction and no longer simply a return to order (Billiani 2013, 849-58). As outlined in Chap. 3, the Italian novel was a multifaceted phenomenon, which lacked a well-defined identity 
because of the still fragmented nature of the publishing industry and the still relatively low numbers of readers, especially if compared to other European nations, such as France and the United Kingdom. Because of the heterogeneous nature of the 'Italian novel' and because of the central role played by translations within the literary field, from the mid-1920s to the mid-1930s the (however present) realist-constructivist dimension ran parallel to other literary currents, such as prosa d'arte, intimist narrative or Modernist writing; and, moreover, it resurfaced later for instance in the visual arts, with Aligi Sassu's Gruppo Rosso and his antiFascist painting La fucilazione nelle Asturie (1935), with the second prize at the Premio Bergamo in 1942 being awarded to Renato Guttuso ${ }^{3}$ as a sign of the importance for the younger generations that the real, articulated as coexistence of the subjective and the objective in their urge to express the tragedy of the war, and held within official State art and art more generally during the final years of the regime. ${ }^{4}$ Or, with Ernesto Treccani's Corrente movement and Corrente journal, which from 1938 to 1940 brought together some of the leading intellectual lights of the generation of critics, writers and artists to survive the regime and to shape the cultural milieu of democratic Italy: Luciano Anceschi, Giulio Carlo Argan, Piero Bigongiari, Luigi Comencini, Carlo Emilio Gadda, ${ }^{5}$ Alberto Lattuada, Eugenio Montale, Vasco Pratolini, Enzo Paci, Salvatore Quasimodo, Luigi Rognoni, Umberto Saba, Vittorio Sereni, ${ }^{6}$ Elio Vittorini. ${ }^{7}$ Corrente saw the cultural crisis Italy was going through as an opportunity for change, and firmly placed national culture in relation to the international scene, while promoting an understanding of the arts as an interdisciplinary practice.

Although the debate on the aesthetics of realism went in many artistic and disciplinary directions, as we have indicated so far, one of its guiding principles was the desire to represent the relationship between Man and his social dimension, between individuality and collectivity: whether taken from the point of view of the avant-garde or as an expression of anti-totality, an illustrative-documentarist form, or an indissoluble unity of the particular and the universal. On a more general level, the debate within the art world revolved around a redefinition of matter, of the real, and of the ethical and moral dimension of subjectivity. 


\section{The Debate}

The Fascist system of the arts had to be constructed in the interstices between the political and the aesthetic spheres in such a way as to reconfigure the boundaries between these two realms and thus redefine the relationship between subjectivity and objectivity, between autonomous and heteronomous practices. Critics Ben-Ghiat and Sechi have noted a strong correlation between youth culture and corporativism, but for the purposes of our argument we will devote more attention to the literary side of the overall dispute (Ben-Ghiat 2001, 106-7; Sechi 1984, 63). ${ }^{8}$ The attitude and politics of youth culture were particularly favourable to such theoretical premises because they sought to rethink the role of the arts in society from an interdisciplinary perspective. Albertina Vittoria has rightly observed how, since the mid-1920s the regime had clearly understood the role culture had to play in the construction of the totalitarian apparatus, and how this ambition became more strongly expressed in the mid-1930s with the involvement of youth culture in this longterm project $(1980,324-26,333-34)$. In the first instance, as far as regime-sponsored art was concerned, this meant not only propaganda in the most general of terms, but the broader question of creating a State art of more enduring significance across the public and personal spaces of the individual.

Whereas Orpheus had an interdisciplinary slant, Il Saggiatore's focus was more philosophical, showing a specific interest in the novel form and in the debate on realism. Alongside, a distinct disposition towards shaping the new intellectual, the two journals also shared a commitment both to the definition of a new type of art focused on the concepts of realism and the sociality of art, and to the materialist foundation of reality from a humanist perspective. Occidente, by contrast, concentrated mainly on literary matters and promoted the Rome-based avant-gardes as well as realist and Modernist European and American prose writing (Ben-Ghiat 2001, 104). All three embodied the denser aesthetic ${ }^{9}$ and political discourse directed at the relationship between subjectivity and objectivity, which was seen as being necessary to fulfil a collective and/or moral function as part of a wider transformation of the individual within the fabric 
of society (Salvagnini 2000, 239-40, 246). Orpheus and Il Saggiatore were still concerned with a 'humanist' understanding of the relationship between subjectivity and objectivity in terms of participation of the self in the definition of the real and vice versa, while the avant-garde circles that fed the position held by Occidente (and earlier publications such as Interplanetario, La Bilancia and La ruota dentata) favoured a more techni$\mathrm{cal}$ and detached approach to the same set of issues. The thread running through all of them is the reflection on the role of the arts in society and an attempt to move away from art for art's sake: put another way, if we exclude state-sponsored propaganda art, the discussion to be had was around the boundaries of heteronomy and autonomy in the arts under a totalitarian, dirigiste regime.

\section{Occidente (Rome, 1932-1935)}

Occidente was published in Rome from the anniversary of the celebrations for the Decennale of the Fascist revolution in October 1932 until the eve of the Ethiopian war in 1935. Its total run of 123-monthly issues enjoyed only a rather limited circulation. It was directed by Armando Ghelardini, who also owned the Edizioni d'Italia. Controversial and unconventional intellectuals such as Umberto Barbaro, Vinicio Paladini and Elio Talarico, together with the omnipresent Massimo Bontempelli, worked closely with Ghelardini. Occidente would eventually be banned in 1935 and Ghelardini placed under virtual arrest. With issue 12 (May-June 1935), the publication was halted, with no explanation given apart from a short article by Ghelardini himself, significantly entitled 'Bilancio', which announced the end of Occidente. Issue thirteen was finished but was confiscated by the Fascist police at the printers, after the editor-in-chief Ghelardini had twice risked house arrest because of the journal's non-orthodox editorial line and the political orientations of some of its contributors (for instance, Umberto Barbaro). ${ }^{10}$

Occidente's opening article stated that the aim of the review was to offer the widest possible overview of world literature: it aspired to the 
transatlantic scope of journals like Orpheus, La Ronda, Il Convegno, Lo spettatore italiano and Solaria, to name but a few similar literary contemporaries and predecessors. Ghelardini described Occidente's ideal reader as 'a cultivated and intelligent man' ('uomo colto ed intelligente') and that his intention was to put Italian writers in touch with foreign writers in order to 'affirm European cultural values' ('affermazione dei valori culturali europei'), although contributions on photography, cinema and photomontage were also published (1932, 'Introduzione.' Occidente 1, no. 1 (October-December): 2). In her analysis of the journal's position within the national cultural field, Alessandra Briganti has shown that, by welcoming the most anti-conventional and, in Fascist terms, anti-bourgeois intellectual voices of the Rome-based SecondFuturist movement, Immaginism, and by paying constant attention to the international literary and artistic scene, Occidente expressed a rather original vision of the shape of the novel $(1988,18)$.

Foreign presences were numerous and varied, and the Parisian scene was not given undue coverage. The first issue featured translations of Aldous Huxley and D. H. Lawrence; Max Beerbohm, James Cain, Hans Canossa, Jean Cocteau, Joseph Conrad, John Dos Passos, William Faulkner, Waldo Frank, Ernest Hemingway, James Joyce, Valery Labraud, Liam O'Flaherty, Franz Werfel, and Virginia Woolf would all be translated in subsequent issues. Alongside British Modernism, new French writing, American realism and German New Objectivity were found examples of the most progressive strands of Italian writing and articles by figures from the regime's centre and fringes alike in a highly eclectic mix: with contributions by Corrado Alvaro, ${ }^{11}$ G. B. Angioletti, Umberto Barbaro, Massimo Bontempelli, Giuseppe Bottai, Anton Giulio Bragaglia, Ennio Flaiano, Francesco Jovine, F. T. Marinetti, ${ }^{12}$ Paolo Orano, Corrado Pavolini, Mario Puccini, Salvatore Quasimodo, Enrico Rocca, Federigo Tozzi, Elio Vittorini, the debate on the novel, in terms of both form and subject matter, was particularly lively. In the first issue, stressing the impending need for aesthetic renewal, Massimo Bontempelli contributed an article in which he defined the spirit of the moment as positive and thus constructive since it was oriented towards 'work and life' ('lavoro e vita') and 'action' ('azione'), and in this 'vitalistic impulse' ('impulso 
vitalistico') he saw the convergence of political and aesthetic aims as also defined by the official debate on State art (1932b. 'Scuola dell'Ottimismo.' Occidente 1, no. 1(October-December): 9, and see Chap. 2). ${ }^{13}$

Throughout its brief existence, Occidente accorded privileged status to the novel whether it be Italian or international. Occidente was truly transatlantic in aspiration: in the first four issues (out of twelve) there were four substantial articles on the novel, followed by another three in subsequent issues, giving a total of seven. Every issue also contained one more or less elaborate article on the landscape (e.g. a well-informed panorama) of the European novel. Overall, however, the most sustained and wide-ranging discussion on the shape and atlas of the novel per se- and not as nationally defined-concerned the limits of realism and of realist narration.

In his 'Considerazioni sul romanzo', the former Immaginist Umberto Barbaro $^{14}$ denounced the abstract rationalism of the avant-gardes as a product of old European culture, an expression of the liberal State:

The need was felt to reclaim technique and a return was made to the carefully constructed and well-thought-out work in its most typical from, the novel: the latter, however, like rationalist architecture and all avantgardisms, is full of self-absorbed voracity, and now it aspires to be nothing but fantasy; nothing but technique, like in detective novels (the old antiartistic need that Guerrazzi was already talking about long ago [...]) or nothing but sociology, morality or content, that is to say, still nothing but fantasy. (1, no. 1 (October-December): 20) ${ }^{15}$

Art has to reject pure rationality (or pure rationalization of forms) because true artistic expression needs to enter into dialogue with everyday reality and avoid abstraction. Rationalist architecture can help in building the metaphorical structure on which the novel relies in order to be integrated aesthetically with the characters' subjective experience: when it fuse together function with conception and design. According to Barbaro, the novel has to depicts various sides of the human experience: it needs to combine the need to tell a story with that of engaging with reality without forgetting that its primary attribute is to be a work of fiction, a journey through the imaginary. The novel, Barbaro adds, is therefore the artistic form that best embodies modernity when it rejects forms of solipsistic 
wandering to embrace a closer contact with objectivity, since ' $[t]$ rue morality in art consists in bringing the reader back into contact with, and constraining him within, the narrow confines of the everyday' (Ibid.:21). ${ }^{16}$ The prose writing had to allow readers to hope for change but it could not merely be a form of escapist distraction from reality: it needed to engage productively, yet fictionally, with objectivity in all its phenomenology whether from a social or an individual point of view but never from an autonomous and de-historicized one. A similar point will emerge from the debate on the novel in Il Saggiatore, as will be discussed below.

The debate on the novel often returns to a common anxiety: how can one move away from 'early twentieth-century liberalism' (Sechi 1984, 67) to find a new way forward, a new utopian literary and social configuration (constructivist and corporative) in order to achieve modernity? In his 1933 article 'Coefficienti nuovi nel romanzo', Elio Talarico makes a point about Decadentism and its lack of construction, being engaged as it was in a self-referential understanding and rendering of objectivity, adding that the novel has to resist slipping into psychology and focus on building solid and composed artistic forms: 'What are we waiting for, then, why don't we begin constructing properly, right now?' (2, no. 3 (April-June): 7$).{ }^{17}$ Talarico and Barbaro saw the new novel, the modern and contemporary novel, as being on the threshold between heteronomous and autonomous literary practices because it had to be moved by a desire both to 'build' a structure, a plot, and to tell a story, which needs to remain a fictional stance, an artefact that is different from a social experiment.

In his 'Rapporto dalla Germania' the former Novecento novelist, journalist Pietro Solari, who spent time in Berlin at the same time as Corrado Alvaro, salutes German New Objectivity because he saw it as a fictional experiment which could be the way forward in preventing further cultural impoverishment by the Italian cultural elites who had become intellectually parasitic and static in their outlook; a situation that the anti-bourgeois politics of the regime was able to rectify (1933, 2, no.5 (October-December): 41). An anonymous note 'Tramonto dell'arte borghese', published in the same issue, echoed this declaration, hailing the end of the bourgeois spirit, as a decadent, inane and damaging force (1933, 2, no.5 (October-December): 65-66). Similar points are reiterated throughout the article: Benedetto Croce, Gabriele D'Annunzio and 
even Oscar Wilde are dismissed without any right to appeal because they do not 'realistically portray' ('rappresentano realisticamente') the content of their novels, which they see as less important than stylistic experiments and lyricism. However, the difference between aestheticism and realism is not based exclusively on method or on content (as Barbaro put it) but also on ethical imperatives. The renewal of the novel, including the renewal of its narrative structures, needed to come from an ethical change: such a transformation fit squarely with that advocated by the regime through its arte di Stato. The Fascist revolution would transform the lives of its citizen because it would change their way of looking at the real, be that their objective reality or their inner one. Occidente was thus against 'eloquenza' and in favour of formal simplicity and directness in prose writing which could reach 'with naturalezza' to the heart of the matter. Youth culture in general and literary culture specifically sided with the regime in its interpretation of the role of the arts as conducive to action and construction, and committed to the social cause.

The novel no longer needs the heroic, solipsistic, gestures of a Julien Sorel, but rather characters who can help build reality and who are ethically convincing, as journalist, writer and translator Enrico Rocca clarified: 'So the children of this century are now called Glaeser, Körmendi, Leipmann e Kästner, Kesten and Süskind? Why is this? Moravia and Gambini, even? [...] This liberation is already a form of morality' (1933, 'Hermann Kesten, o delle ragioni del cuore' 2, no. 2 (January-March): 53). ${ }^{18}$ Rocca is not only calling for morally sound arts but also for a more competitive national novel, which could be placed side by side with the genre's contemporary expressions. In the section on 'Europa letteraria', literary critic Giacomo Antonini in a long article titled 'Narratori italiani' a few months later concluded that new writers had to establish a 'wider contact with the public' ('largo contatto con il pubblico') since, like Körmendi's best-selling translated Hungarian novels, they needed to 'go to the people' ('andare al popolo') and to do so such novels have to bear an ethical message (1933, 3, no.7 (April-June): 26).

In his article 'Tecnica e mondo moderno', mathematician and scientist Umberto Forti went a step further in demarcating literary spaces: 'A culture which is estranged from technology and science is too much like those grand old nineteenth-century houses which had two reception 
rooms, plenty of grand features, but not even the tiniest of bathrooms' (1933, 3, no. 9 (October-December): 13). ${ }^{19}$ While complaining about the still 'humanistic' attitude displayed by Italian culture, Forti added that such literature could not address the basic demands of humanity, only frivolous accessories. On this occasion, the architectural metaphor indicated a new morality but also a new configuration of the novel's thematic repertoire. The novel could and had to engage with the everyday and no longer treat it as marginal: it needed to purse a style without ornament ${ }^{20}$ (Adolf Loos again) as well as a detached approach to the subject matter. Technique, furthermore, was now synonymous with the ordinary and not with a means of constructing alternative words (such as in surrealism, for example). ${ }^{21}$ The reference to architecture here brings us back to the debates on the social role of architecture: Figini and Pollini's Casa elettrica was a manifesto of new technologies, markedly in the kitchen ${ }^{22}$; Adriano Olivetti's expansion of the Ivrea factory foresaw the integration between the daily lives of his employees and the industrial and productive apparatus within a utopian, enlightened Gropiesque vision, able to create individual spaces which could also be collective, rationalized and harmonious. La Sapienza ${ }^{23}$ was the city and factory of knowledge production (see Chap. 7).

Occidente, then, showcased a complex cultural problem: by following the paradigm of avant-gardist rebellion against tradition while also indirectly echoing the regime's campaign for a new ethical system to support the anthropological revolution, it allowed intellectuals with various political orientations to show how they aimed to transform the arts into a set of constructivist-collective movements, ${ }^{24}$ which could in turn contribute to building a new, aerial even, aesthetic landscape. This question is lucidly explained by critic Antonio Valenti in the mainstream publication L'Italia letteraria on 14 January 1934 in an article entitled 'Realtà dell'arte'. He talked about a 'realismo spirituale', which was not simply a way of dealing with everyday life but rather the outcome of a spiritual revolution, an anthropological revolution affecting the very essence of being a citizen and an individual. The novel has an ethical imperative because it executes a pedagogical function in this respect (1934, 19, no. 2 (14 January): 1). Such a function cannot be performed through a paternalistic gaze (whether Croce's or that of the avant-gardes and D'Annunzio), as this would be too technical, solipsistic and, in sum, degenerate. 


\section{Orpheus (Milan, 1932-1934)}

Published in Milan from December 1932 to March 1934, Orpheus also had transatlantic aspirations. The journal was edited by a group of young middle-class intellectuals and writers who gravitated around the Università Statale and the Accademia di Brera, most notably Enzo Paci and Luciano Anceschi. Both born in 1911, they eventually became, respectively, a leading exponent of Italian philosophical existentialism and a noted literary critic in post-war Italy, as well as professors at Pavia-Milan and Bologna. In the 1930s at the Università Statale, Paci and Anceschi worked under the supervision of the philosopher Antonio Banfi, who in 1925 signed the Manifesto of anti-Fascist intellectuals and maintained a coherent distance from the regime. The journal's director, Pietro Torchi, was a musician who always encouraged the review to remain progressive in ethos and outlook. A medium-sized monthly review, it was sold at 2 lire per issue and a total of thirteen issues were published. ${ }^{25}$ It devoted very little space to advertising, in favour of a modernist simplicity of line and style, with a Spartan front cover featuring only the title. It included a good selection of regular sections, containing an average of four or five long articles per issue (sometimes in the form of appunti, 'notes'), and a substantial section featuring longer 'Recensioni' and shorter reviews, as well as 'Cronache', 'Notiziario' and 'Notizie', often focusing on foreign works either in the original language or in translation (often into French and without the Italian translation) as well as on other Italian and foreign reviews.

Orpheus embraced multidisciplinary. But, it stood out from other comparable, non-mainstream initiatives, such as L'Orto (1931-1939), Pan (1933-1935), Pègaso (1929-1933) and Solaria (1926-1934), on account of its patently interdisciplinary scope as well as for its even stronger inclination towards the social dimension of the arts within 'Fascist mass society' - in line with Il Saggiatore. In a letter dated May 1933 to 'Cari amici del Saggiatore', Anceschi suggested a collaboration between the two 'movements' because of their shared interest in artistic matters and their shared desire to revise the relationship between 'art and society' (Anceschi archive, folder 'Corrispondenza Orpheus', b. 11). Anceschi was also keen to establish collaborations with Quadrante and Bardi, Critica fascista and the Rivista di psicoanalisi. ${ }^{26}$ Amongst the key contributors to 
the review we find a rather interdisciplinary set of expertise: the prominent art critic Raffaello Giolli, Riccardo Picozzi-a musician and opera teacher, the publishers Franco Formiggini and Alberto Mondadori, the academic Lorenza Maranini who was to become a leading French literature specialist, the film critic Eva Randi, Aldo Valcarenghi (son of the co-director of the Ricordi publishing house and organizer in 1931 of the pro-Toscanini manifestation), the sculptors Luigi Grosso and Giacomo Manzú, ${ }^{27}$ the architects Isaac Saporta, Clara Valente, Federica Vecchietti, Maria and Clara Albini, Käte Bernhardt, the writer Elio Vittorini, the artist Riccardo Crippa, and the Jewish psychiatrist and academic Antonio Pesenti. The review included, unusually, eight women.

In 1932, the year of the celebrations for the Decennale of the Fascist 'revolution' and the abolition of artistic groupings in the USSR, Orpheus adopted a much more explicit and 'militant' position than Occidente, seeking to transform radically the prosa d'arte, the lyrical prose so fiercely championed by $L a$ Ronda, into a collective writing able (and thus enabling the orfisti) to react to the demands of a modern, Fascist society. ${ }^{28}$ Compared to Occidente, Orpheus has a more structured approach to aesthetics and political issues: during its lifetime it carried out a systematic critique of the idea of autonomy in the arts.

In September 1933, in response to a general consultation with its readers, Paci declared that a new art 'will have to be constructed and based above all on two concepts: the concept of "collectivism" and the concept of "historical realism"' as 'transpositions onto the cultural plane of realities which are presently alive and in motion on the political and economic level' (1933, 'In margine ad un'inchiesta.' 2, no. 6-8 (July-September): 1). ${ }^{29}$ Paci explicitly connected youth culture with economic renewal and indirectly connected the arts with an economic problem, which in the 1930s was that of the State as not only an ethical force but also a corporate one. In November 1933, discussing Orpheus' contribution to the survey carried out by Il Saggiatore on the same topic, in the opening article Anceschi reinforced the point already made a couple of months before, by claiming that the new art championed by the journal was ingrained in the principle that 'dynamic realism, $[. .$.$] determined by its relationship with life$ [...], constitutes the meaning of our collectivist Aufklärung. ${ }^{30}$ Here the Milanese intellectual denied the value of abstract speculations since for 
him to theorize meant to ground one's reflections within a clear historical paradigm, a duty which needed to be performed by youth magazines. By neglecting the idea of realism as a static representation of reality, the new art therefore needed to reconfigure the relationship between individuality and collectivity. Their task would now be to 'find a new law of connection between the individual and society, between the single individual and the collectivity' (1933, 'Appunti per la definizione di un'atteggiamento.' 2, no. 9 (November): 4). ${ }^{31}$ This 'moral and intellectual commitment' ('atteggiamento morale e intellettuale') could not tolerate indifference if it intended to forge a more profound theoretical and critical awareness of sociability in the arts, which had to translate into radically different forms of individual participation in the collective. In other words, without rejecting Fascist ideology per se, these young intellectuals wanted to 'explain' and 'clarify' ('spiegare e chiarire') further their understanding of the relationship between art and the individual as a social entity in order to produce an alternative scenario to those of art as propaganda or statesupported art. Once more, in response to the same survey in Il Saggiatore in December 1933, in the editorial Orpheus acknowledged that 'if politics is the basis of everything, then the corporative question, which expresses the most concrete revolutionary innovation of our current political configuration, is consequently the fundamental question we face' where 'social realism' ('realismo sociale') can find its 'concrete expression in a political form in movement, a synthesis and an instrument of the revolution' (1933, 'I giovani e la nuova cultura.' 2, no. 10 (December): 1-2). ${ }^{32}$

Thus Orpheus' brand of international realismo storico, in line with that promoted by similar reviews such as Il Saggiatore, was a more general expression of revolutionary humanism and less so of technological avantgardism, which could and would bring artists and citizens-preferably collectively-back to the art of their Nation and to its social context. Moreover, by laying claim to the economic and social appeal of all artistic elements, in line with the aims of 1930s Italian corporative totalitarian art, Orpheus not only renounced the liberal idea of art as pure and estranged from practical existence, but also rejected its use as a form of total control of individuals through their consciousness. It is worth noting here that mural painting as the vehicle to represent the corporative totalitarian State started to emerge and gain a hegemonic position from 1933 onwards. ${ }^{33}$ 
In a departure from the regime's position, however, there was no mention of any State control over cultural matters; art was an autonomous field of production and moreover was ruled independently. The rappel $\grave{a}$ l'ordre, in this instance, took the form of a return to the logical acceptance of art as an autonomous form of collective expression, albeit one closely embedded in the social reality of its production and circulation. It was Enzo Paci who finally brought all these elements together in his long 1933 review of Benedetto Croce's influential Poesia popolare e poesia d'arte (1933, 2, no. 3 (April): 17-19). Discussing Croce's argument on the productive relationship between the folklore tradition and artistic poetry, he unequivocally rejected the notion of the 'autonomy of the artwork' and declared his unconditional faith in any form of literary expression, which reflected its historical context. In this important review, as elsewhere in his long, incisive articles on art and politics, Paci anticipated the post-war rejection of Croce and laid the foundations of the soon-to-be hegemonic historicist tradition of critical engagement with the arts.

Orpheus also published on cinema, photography, visual art, music and, crucially, printed three articles about international architecture. In the opening issue, the young architect Alberto Franco Schwartz wrote an article on the new architecture in France which, he argued, had the merit of providing the environment and the climate for the 'most complete and vital theoretical formulation of the problems of the new architecture in the entire world' $(1933,2$, no.1 (January): 14$) .{ }^{34}$ In the May-June issue of the same year, Isaac Saporta, a student of Walter Gropius, published 'Architettura razionale' where he drew a parallel between the role of new architecture and the New Man in creating a modern society (ibid., no. 4-5: 12-13). This line of argument was also embraced by painter Pio Ponti in 'Architettura e aderanza alla realtà', in the same issue but this time dealing with Italy (ibid.:14-15). In Italy, as in the rest of Europe, he identified clear similarities between the ways in which architecture, society and aesthetic rationalization participated in the process of social modernization. The writing on contemporary aesthetics published in Orpheus thus clearly shows how the novel, the literary field and the other arts must be read as dynamic and historicized manifestations of the real, while presenting a modern view of society as a site which can be shaped, transformed and modernized by the arts. 
Whether or not it is in a state of flux, of constant evolution and crisis, art can never be extricated from its historicity. By establishing such an unbreakable connection between text and context, Orpheus moved away from Benedetto Croce's aesthetic reflection and Decadentism's lack of any moral concern or historical awareness, instead drawing closer to European experiments, such as German New Objectivity, transatlantic modernism and rationalist architecture, and crucially closer to a deeper understanding of the role played by the arts in moulding the social sphere.

\section{Il Saggiatore (Rome, 1930-1933)}

As already mentioned, in 1933 Il Saggiatore launched an 'inchiesta' ('survey') of the new Fascist culture and its generational divides, thereby bringing to an ideal closure our analysis of the arts and Fascist culture under the banner of realism. Amongst the many responses to the inchiesta (including contributions from Bragaglia, Marinetti and Sarfatti), the consensus yet again seemed to gravitate around the idea that the new intellectual generation had to embrace an idea of culture, which took into account the arts' practical role in society, thereby rejecting any form of idealism in favour of pragmatism (Carpi 1981, 78-81). European realism in particular played an important role as an example of the arts' social mission, since it represented just such a rejection of idealism (Voza 1981, 65-105; Tarquini 2011, 175-76; Ben-Ghiat 2001, 102-22; Sechi 1984, 63-108).

Il Saggiatore was very similar in its stance to the journals we have discussed so far: short-lived, rich in debates, and attuned to the latest artistic developments worldwide. After the Florentine Leonardo (1903-1907), Il Saggiatore was the most philosophical journal published in Italy in the first half of the twentieth century. And, just like its illustrious predecessor, it welcomed pragmatism as the main philosophical prism through which to evaluate every other artistic current, thus clearly rejecting Croce and Gentile's brand of idealism. Its editor was Luigi de Crecchio Parladore, a lawyer and a State functionary, assisted by intellectuals of the standing of Domenico Carella and Giorgio Granata, at the time still university students, Nicola Perrotti, a medical doctor who would also practise as a 
psychiatrist and, Attilio Riccio, a writer close to 900 and Bontempelli. The relationship between artistic creation and psychoanalysis was discussed extensively, thereby creating a more varied intellectual landscape within the journal. Several other intellectual figures of note drawn from Occidente and Orpheus as well as avant-garde circles, contributed, including: Corrado Alvaro, Luciano Anceschi, Umberto Barbaro, P. M. Bardi, Massimo Bontempelli, Corrado Pavolini, Mario Puccini, Emilio Radius, Elio Vittorini, Bonaventura Tecchi and Dino Terra. All these names played key roles both at the fringes and at the centre of the cultural apparatus of the dictatorship, and they found these sorts of cultural venues to be especially useful arenas for debate.

Although not explicitly focused on the arts, Il Saggiatore contributed to the philosophical discussion underpinning the idea of culture itself during the regime. In less than three years, it conducted two major surveys, the first dedicated to the new generation of intellectuals, from March to June 1932, and the second examining the 'new culture' in October 1933. From 1933 onwards, one can simultaneously note a sharp intensification in the regime's anti-bourgeois campaign, which was intrinsically associated with a stronger role for corporativism in directing the regime's cultural campaign (Parlato 2000, 112; Santomassimo 2006, 102-03). Thus, to a certain extent, it is safe to assume that the more experimental and militant cultural debates followed — albeit indirectlytop-down instructions to promote collectivity, the new aesthetics and realism.

In Il Saggiatore, the debate on realism was unambiguously conducted in parallel to that on the new culture and the philosophical debate regarding the limits of individual and collective agency. The main difference introduced by this debate on the relationship between the political and aesthetic spheres was the existential-humanistic element, described as the distinctive trait of the generation of men and women living under the Fascist regime but often imbued with rather mystical and spiritual connotations. Sechi has studied the journal extensively and drawn some definitive conclusions on the role of pragmatism as a counterpoint to the Croce-Gentile axis and on the 'materialist refounding' of both reality and the new literature for the 'present moment' (Sechi 1984, 84; see, e.g. Domenico Carella and Attilio Riccio, 1931, 'Morte dell'idealismo.' 
Il Saggiatore 2, no. 3 (May): 101-05). ${ }^{35}$ We will, therefore, concentrate here on the importance of realism for prose writing, and also on its limits. From a strictly philosophical—as opposed to literary-point of view, Il Saggiatore was against bourgeois prose writing and in favour of art forms connected with their social context, since it insisted that the 'novel' had to reflect lived experience (Giorgio Granata, 1930, 'Dei giovani.' 1, no. 1 (March): 14). As artists, writers had the moral responsibility to address the naked reality before them, and as in all the fields we have analysed thus far, the issue of realism and morality was discussed with some regularity. However, the debate which unfolded in the Rome-based journal introduced a new element: the relationship between subjectivity and objectivity in building a new brand of realism, a question raised in Mario Pannunzio's two interventions specifically addressing the debate on the novel. In his 'Del romanzo', he described the act of writing as an 'X-ray' of reality and its contradictions. ${ }^{36,37} 1930$ s realism, he argued, could not simply reflect the surface of reality but had to use its techniques to dig into the depths and intricacies of the world and provide a more nuanced picture (1932, 2, no. 11 (January): 432-38).

This said, it was important not to lose sight of the pursuit for complete factual anonymity, as Attilio Riccio had already pointed out in his reading of Borgese's Tempo di edificare and, we could add, as Bontempelli had called for as foundational to the act of writing (see Chap. 5). Riccio objected to Borgese's apparent side-stepping of the psychological dimension of artistic creation in his call to build a new architecture for the novel since 'the artwork has to be at the same time real and constructed, the architectural idea needs to lose its transcendental nature and transform itself into a ductile figure, ready to welcome the emotions produce by the real' (1931, 'In margine all'ultimo Borgese.' 2, no. 9 (November): 337-38). ${ }^{38}$ In June 1932, meanwhile, Giorgio Prosperi published an article entitled 'Realismo e impersonalità'. He argued that realism is based on a process of selection and construction and not on that of developing a close association between art and life, citing to this effect playwright Luigi ${ }^{39}$ Pirandello's Sei personaggi in cerca d'autore as an example of realist narration on account of the play's metanarrative construction, abolition of the fourth wall and its open-endedness. For, he explained 'In place of analytical fragmentism ever greater preference is being given to construc- 
tion, to content, to sentiment, in other words to works which have a voice' (1932, 2, no.12: 486). ${ }^{40}$ The type of realism theorized in Il Saggiatore, then, was not a form of pure objectivity offering a direct representation of the real (not even of the collective real) but rather a speculative type of objectivity filtered through individual experience to create a new naturalism (Mario Pannunzio, 'Necessità del romanzo.' 3, no. 4 (June): 154-62; see Moravia, ${ }^{41}$ Chap. 7). In Pannunzio's words, novelists have to interpret and deform reality through their own technical language. This language has to abolish punctuation, favour interior monologue, and create surprising syntactical connections in order to be analytical and 'radiographic' rather than descriptive. Dialogues play a crucial role in this since they can prismatically reveal subjective positions and they can do so simultaneously. Moreover, the journal published reviews of John Dos Passos, Aldous Huxley, D. H. Lawrence, Virginia Woolf and the novelists of the German New Objectivity, thus offering its readers both a plethora of narrative and theoretical choices, and giving an idea of the spectrum of alternatives available in Italy and elsewhere. Other interventions on realism included Domenico Carella's forceful claim that culture as a whole cannot be detached from life if it wants to be meaningful and gain social relevance, and De Crecchio's call a few months later for committed artists who are not confined within a solipsistic understanding of the real, like Michele in Gli indifferenti or Filippo Rubè ${ }^{42}$ in the eponymous novel by Borgese, but are active participants in the construction and modernization of the social sphere (1932, 'Questa realtà.' 3, no. 9 (November): 337-42, and 1933, 'Funzionalità dell'Arte.' 4, no. 2 (April): 59-63, and see Chap. 3).

Despite its philosophical orientation and its lack of a dedicated debate on the novel per se in order to focus more on theories of realism, Il Saggiatore reiterated some of the key principles we have discussed regarding the novel and architecture: construction, social context, morality and stylistic simplification. Its originality lay in how it raised these questions to a higher theoretical level than ever before, while reintroducing the importance of subjectivity as a cardinal point in the definition of the artistic sphere and of the aesthetic experience (from a psychoanalytical and philosophical perspective). The themes of morality, reality, construction, context and tradition recur constantly in the debates analysed here, 
whether these notions are explicitly connected to architecture or to the novel, or used more generally to address the regime's cultural policies on the arts, collectivism and corporativism. In both the aesthetic and political spheres, this constant revisiting of the same topics is indicative of a concerted effort and a distinct programmatic intention, which, as we will see in the final chapter, were put into practice by writers and architects alike throughout the Ventennio, following a trajectory delineated by the broader contextual debates.

\section{Notes}

1. See Giò Ponti's article on 17 September 1933 about architecture and the other arts 'Il "momento" dell'architettura in Italia.' Quadrivio 1, no. 7: 1.

2. For a systematic analysis of the Roman underground movements, and for a detailed scrutiny of the Futurist, communist, anarchist and Fascist journals, which populated it, see Mondello (1990).

3. http://dialecticsofmodernity.manchester.ac.uk/essay/490

4. Fagone discusses extensively the relationship between Sassu, Corrente and the idea of expressionistic realism, fused with that of heroic mythology, as together seen as an antidote to the Fascist regime's brutality and progressive closure. Sassu was arrested in 1937 and released from prison in 1938 due to Marinetti's mediation (2001, 189-96).

5. http://dialecticsofmodernity.manchester.ac.uk/essay/488

6. http://dialecticsofmodernity.manchester.ac.uk/essay/488

7. On the policies about State art, the $2 \%$ law, and the role played by Bottai in the 1940s as indirect patron of the arts, see Vivarelli (1993, 24-38), and the volume edited by Alessandro Masi (1992).

8. On regime policies of youth culture patronage, Ruth Ben-Ghiat points out that contributors to journals such as Il Saggiatore and L'Universale and rationalist architects alike received subsidies from the regime, and much more regularly after 1933 (2001, 108-09).

9. http://dialecticsofmodernity.manchester.ac.uk/tag/aesthetic-theorization

10. Paolo Flores, Vinicio Paladini and Dino Terra were all closely associated with anarcho-communist circles (Mondello 1990, 67-70). Ghelardini was spared house arrest thanks to personal interventions by Ministers Giuseppe Bottai and Galeazzo Ciano. Bottai published an article on 
literature and corporativism in 1935 entitled 'Appunti sulla letteratura corporativa.' 4, n. 12 (August): 11-16. Nevertheless, the journal had to be closed indefinitely.

11. http://dialecticsofmodernity.manchester.ac.uk/essay/437

12. http://dialecticsofmodernity.manchester.ac.uk/essay/455

13. Bontempelli is an admirer of Verga and in n. 10 there are some unpublished letters by the Sicilian writer.

14. http://dialecticsofmodernity.manchester.ac.uk/essay/454

15. 'Si è sentito il bisogno di recuperare la tecnica e si è tornati all'opera costruita e pensata, nella sua forma tipica, il romanzo: ma esso, come l'architettura razionalista, e come gli avanguardismi, è pieno di eautonotimerumena voracità, oggi aspira ad essere tutta fantasia; tutta tecnica, come nei romanzi gialli (vecchio bisogno antiartistico di cui parlava già Guerrazzi [...]) o tutta sociologia e morale o contenuto, cioè ancora tutta fantasia.'

16. 'La vera moralità dell'arte sta nel ricongiungere, riconstringere nelle angustie della quotidianità il lettore.'

17. 'Che cosa si aspetta dunque, perché non costruire davvero, subito?'

18. 'I figli del secolo oggi si chiamano, Glaeser, Körmendi, Leipmann e Kästner, Kester? e perché? anche Moravia e Gambini? [...] Questa liberazione è già moralità.'

19. 'Una cultura estraniata dalla tecnica e dalla scienza somiglia troppo alla vecchie case umbertine, che avevano due salotti, molte cose di pretesa, ma nemmeno una stanzetta da bagno.'

20. http://dialecticsofmodernity.manchester.ac.uk/tag/architectural-principle.

21. See Sartoris' article (1933) on surrealism and new architecture in Quadrante, cit.

22. http://dialecticsofmodernity.manchester.ac.uk/artefact/28

23. http://dialecticsofmodernity.manchester.ac.uk/artefact/41; http://dialecticsofmodernity.manchester.ac.uk/essay/497; http://dialecticsofmodernity.manchester.ac.uk/essay/497

24. http://dialecticsofmodernity.manchester.ac.uk/tag/collectivity

25. From 1 November 1933 the price increased to 3 lire because of a format change, which meant a larger size and more illustrations. Orpheus had 50 subscribers but was distributed in batches of a hundred copies in bookstores.

26. A note in the folder 'Corrispondenza Orpheus' lists 42 journals for Orpheus to be in contact with: most notably, Camminare, Domus, Frontespizio, Il Saggiatore, L'Italia letteraria, L'Orto, L'Universale, the 
Nouvelle Revue Françoise, Occidente, Il Milione, Quandrante, Oggi, La rassegna musicale, Scenario, Il Convegno, L'Italia che scrive, Arti plastiche, Solaria, Circoli, L'Italiano, Il selvaggio, Nuova Antologia, Il secolo fascista, Tempo nostro, Critica fascista. The list includes also 46 subscribers (Anceschi archive, 'Corrispondenza Orpheus', b. 11).

27. http://dialecticsofmodernity.manchester.ac.uk/essay/430

28. A profound dislike for Croce and the prosa d'arte i salso expressed privately by Pietro Tronchi in a letter dated 12 September 1933 to Luciano Anceschi (Anceschi, folder 'Corrdispondenza Orpheus', b. 11).

29. 'si dovrà costruire e basare sopra tutto su due concetti: il concetto di "collettivismo" e il concetto di "realismo storico"' as 'trasposizioni sul piano culturale di realtà ormai viventi ed in moto su quello politico e su quello economico.'

30. 'realismo dinamico, [...] determinato dai rapporti con la vita. [...], costituisce il senso della nostra Aufklärung collettivista.'

31. 'trovare una nuova legge di connesione tra l'individuo e la società, tra il singolo e la collettivià.'

32. 'se la politica è il fondamento di tutto, il problema corporativo, che esprime l'innovazione rivoluzionaria più concreta della nostra attuale politica, è conseguentemente il problema fondamentale' 'espressione concreta in una forma politica in moto, sintesi e strumento della Rivoluzione.'

33. On this point, see Fagone (2001, 19-23, 26-46).

34. 'formulazione teorica più complete e vive dei problemi della nuova architettura in tutto il mondo'. For instance, Schwartz also wrote articles on Frankfurt-based popular architecture and housing for the Rassegna dell'architettura.

35. Other significant contributions on the debate on realism are: Nicola Carella, 1931, 'Omaggio al realismo.' 1, no. 11 (January): 351-65; and Francesca Bruno, 1931, 'Realismo germanico.' 2, no. 4 (June): 160-65 with a specific reference to the practice of 'lucid realism' in prose writing championed by the German New Objectivity movement, ibid.:164.

36. http://dialecticsofmodernity.manchester.ac.uk/essay/449

37. In 1932 Enrico Emanuelli published a newly realist novel entitled precisely Radiografia di una notte and in 1934 Mario Soldati the cinéroman 24 ore in uno studio cinematografico, both with the Milanese publisher Ceschina. On the critical reception of the novel, especially by his contemporaries and on Emanuelli's borrowing from European Modernist and contemporary novels, see Ben-Ghiat (2001: 59-61). 
38. 'L'opera d'arte deve essere allo stesso tempo reale e costruita, l'architettura deve perdere la sua natura trascendentale e trasformarsi in una figura duttile, pronta ad accogliere i dati emozionali della realtà.'

39. http://dialecticsofmodernity.manchester.ac.uk/essay/459

40. 'Al frammentismo analitico si preferisce sempre di più la costruzione, il contenuto, il sentimento, cioè l'opera che abbia una voce.'

41. http://dialecticsofmodernity.manchester.ac.uk/essay/456

42. http://dialecticsofmodernity.manchester.ac.uk/essay/440

Open Access This chapter is licensed under the terms of the Creative Commons Attribution 4.0 International License (http://creativecommons.org/ licenses/by/4.0/), which permits use, sharing, adaptation, distribution and reproduction in any medium or format, as long as you give appropriate credit to the original author(s) and the source, provide a link to the Creative Commons licence and indicate if changes were made.

The images or other third party material in this chapter are included in the chapter's Creative Commons licence, unless indicated otherwise in a credit line to the material. If material is not included in the chapter's Creative Commons licence and your intended use is not permitted by statutory regulation or exceeds the permitted use, you will need to obtain permission directly from the copyright holder.

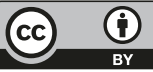

